\title{
A preliminary study of seismic microzonation of Concepción based on microtremors, geology and damages patterns
}

\section{Estudio preliminar de microzonificación sísmica de Concepción basado en microvibraciones, geología y patrones de daño}

Fecha de entrega: 18 de enero 2012

Fecha de aceptación: 5 de junio 2012

\section{Felipe Leyton ${ }^{1}$, Gonzalo Montalva² y Paola Ramírez ${ }^{3}$}

${ }^{1}$ Escuela de Ingeniería en Obras Civiles, Universidad Diego Portales, Ejército 441, Santiago, Chile, felipe.leyton@udp.cl ${ }^{2}$ Departamento de Ingeniería Civil, Universidad de Concepción, Edmundo Larenas s/n, Concepción, Chile, gmontalva@udec.cl ${ }^{3}$ SERNAGEOMIN, Avda. Santa María 0104, Providencia, Santiago, Chile,pramirez@sernageomin.cl

We perform microtremors measurements at Concepción and compute the predominant frequency using horizontal-to-vertical spectral ratio (HVSR). We compare these results with the surface geology and several geotechnical surveys existing in the region, enabling a general characterization of the area. We present and complement these results with observations of damage produced by the $M_{w} 8.8$ Maule 2010 earthquake. Preliminary results show the presence of fine-grained materials in the area characterized by very low predominant frequency (lower than $1.5 \mathrm{~Hz}$ ), which might explain the extensive damage observed at Concepción and surroundings.

Keywords: seismic microzonation, Concepción geology, microtremors' HVSR
Se realizan mediciones de microvibraciones en Concepción y se calcula la frecuencia predominante usando la razón espectral horizontal a vertical HVSR. Se comparan estos resultados con la geología superficial y varios antecedentes geotécnicos existentes en la región, permitiendo una caracterización general del área. Se presentan y complementan estos resultados con observaciones de daño producto del terremoto de Maule 2010 de $M_{w}=8.8$. Resultados preliminares muestran la presencia de materiales finos en el área caracterizados por frecuencias predominantes muy bajas (menores a $1.5 \mathrm{~Hz}$ ), lo cual podría explicar el daño extensivo observado en Concepción y sus alrededores.

Palabras clave: microzonificación sísmica, geología de Concepción, HVSR de microvibraciones

\section{INTRODUCTION}

Concepción has witnessed several large earthquakes with magnitudes larger than 8.0, with a special mention to the earthquakes of 1570 (8.6), 1657 (8.3), 1751 (8.9), 1835 (8.4), 1960 (9.5), and the recent $2010\left(\mathrm{M}_{\mathrm{w}}=8.8\right)$. Most of these large events were followed by a destructive tsunami that desolated the coast. All of these earthquakes produced large seismic intensities at Concepción, with estimated values ranging from VIII up to XI (Susa 2004). For the recent Maule 2010 event, at Concepción was reported an MSK seismic intensity (Imsk) between VII and VIII; while less than $10 \mathrm{~km}$ to the North, the neighboring cities of Penco and Talcahuano reported Imsk of VI and VII, respectively (Astroza et al. 2010). This difference in the damage produced by the earthquake can only be explained considering local site conditions. Similar observations have been made in Santiago where, during the Valparaíso 1906 earthquake (Montessus de Ballore 1915) and 1985 earthquake (Monge 1986), the surface geology presented a clear influence. During this last event, Astroza et al. (1989) reported a difference between 0.5 and 2.0 in seismic intensity within close regions: Las Condes $(\mathrm{Imsk}=\mathrm{VI})$ and Pudahuel (Imsk = VIII-IX) (see Menéndez, 1991, for further details). Astroza and Monge (1991) showed that, for the 1985 earthquake, the largest amplifications of accelerations were produced in fine-grained and fluvial deposits. 
Since the early work of Kanai (1957) on the estimation of site amplification using microtremors, many authors have devoted their work to estimate a site's dynamic characteristics in a fast and economic way. Kanai (1957) made the hypothesis that microtremors can be considered as white noise in the frequency range of interest ( 0.1 to 10 $\mathrm{Hz}$ ); hence, any observed amplification should be produced by the soil's dynamic properties. However, Udwadia and Trifunac (1973) noted that the microtremors acceleration spectra changed during the day, showing that not only the dynamic response of the soil influenced the spectra, but also the sources (human activity). Later, Nogoshi and Igarashi $(1970,1971)$ proposed the computation of the horizontal over vertical spectral ratio (HVSR), in order to remove the effect of the source, and applied this ratio to measurements in urban settlements in Japan. Nakamura (1989, 1996, 2000) extensively popularized this concept, making the use of microtremors' HVSR a corner stone in microzonation studies in large cities (Bard 1998; Bard et al. 2005).

Several studies have shown a correlation between the peak observed in microtremors' HVSR and the predominant frequency of the soil (Lermo and Chávez-García 1993; Lachet et al. 1996; Konno and Ohmachi 1998; BonnefoyClaudet et al. 2006a, 2006b, 2008, 2009); however, their amplitudes have not been able to relate to site amplifications (Field and Jacob 1995; Lachet et al., 1996). Other authors have shown other limitations to the HVSR technique, mainly due to complexities in the subsoil (Chávez-García et al. 2007; Bonnefoy-Claudet et al. 2009). On the other hand, recently Leyton and Ruiz (2011) have shown similar behavior of the soil observed using strong-motion accelerograms and microtremors, enabling the use of this last method to estimate the seismic response of the site during a large earthquake. Hence, this information represents a crucial parameter in seismic microzonation studies.

In this paper, we propose a microzonation for Concepción (including some areas of Hualpén, Talcahuano, San Pedro de la Paz and Chiguayante) based on surface geology and predominant frequency obtained from microtremors' HVSR, complemented with observations of damage produced by the Maule 2010 earthquake. In the present study we have focused mainly on the city of Concepción, presenting the first results of the proposed seismic microzonation.

\section{METHODOLOGY}

Nakamura $(1989,2000)$ popularized the used of the horizontal-to-vertical component spectral ratio (HVSR) from microtremors as an effective and economic tool to estimate the predominant vibration frequency of soils. In this study, we used a 3-component, 4.5-Hz GVB instrument to make the measurements, which gives a reliable answer down to $0.1 \mathrm{~Hz}$ and has been successfully used in previous studies (Leyton et al. 2011; Leyton and Ruiz 2011). At each point, we recorded accelerations from ambient noise for a time window of at least $20 \mathrm{~min}$, depending on the level of human activity, as recommended for microzonation studies (Bard et al. 2005). Later, we processed the data dividing the total time window into 60 -sec subwindows. Then, we computed the Fourier transform of each component and added the modulus of both horizontals creating a composed horizontal that assumes perfect coherency between them. Note that this last quantity is the largest possible estimator of the power observed at the horizontal components. Later on, we use a homogenous filter in a logarithmic scale (Konno and Ohmachi 1998) to smooth each spectrum and computation of the horizontal over vertical spectral ratio is carried out. Due to the fact that we used one-minute length time windows, we obtain, at least, 20 independent estimations, and the error is calculated for each frequency by means of the geometric standard deviation. Nevertheless, we also computed the HVSR for each horizontal component separately, in order to have an estimator of possible preferred direction; a couple of examples are shown in Figure 1 and are discussed in detail in the following paragraph.

Figure 1 shows the results for 2 cases: left panels from (a) to (c) correspond to a measurement with a peak at 0.7 $\mathrm{Hz}$, but with high noise at lower frequencies, while on the right side from (d) to (f), is a measurement with a clear peak at $1.0 \mathrm{~Hz}$. In order to test how robust this estimation is we plotted in the lower panels, (c) and (f), the composed HVSR (continuous line), the HVSR for each horizontal component (dashed lines), and the corresponding standard deviation (gray area). At a first glance, we can see that 

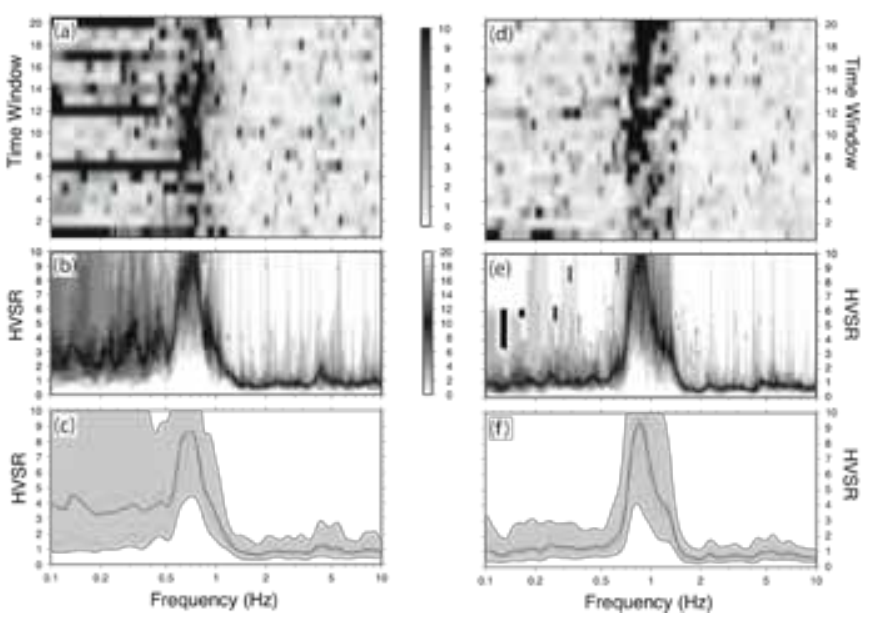

Figure 1: Examples of microtremors' horizontal-to-vertical spectral ratio (HVSR) performed at Concepción. Lower panels, (c) and (f), show the geometric average HVSR (continuous line), HVSR for each horizontal component (dashed lines), and the standard deviation in log-scale (gray area). Middle panels (b) and (e) show the number of time windows exceeding the corresponding HVSR amplitude, following the scale on the middle; hence, black represents the statistical mode. Top panels (a) and (d) show the HVSR for each 1 min time window, being the color proportional to HVSR, following the scale on the middle. Note that panels on the left represent measurements with high level of noise at lower frequencies, while panels on the right correspond to a point with a clear peak at $1 \mathrm{~Hz}$.

the error of the measurements on the left panels (a) to (c) is much larger than for the one on the right panels (d) to (e), especially at lower frequencies. We also plotted the HVSR for each 1 min time windows, usually considering 20 windows total, as shown in panels (a) and (d); the gray gradation is proportional to the spectral ratio, following the scale on the middle. From panel (a) we can see that most windows show a peak at $0.7 \mathrm{~Hz}$; however, windows 1,7 , 12, and 20 have high HVSR at low frequencies, increasing the error in this range. On the other hand, panel (e) presents almost all 1 min time windows with a clear peak at 1.0 $\mathrm{Hz}$, except from the first one, probably influenced by the deployment at the field. Further testing is performed in panels (b) and (e) for both measurements; these panels present the number of one min time windows that exceeds the corresponding HVSR value, following the scale on the middle. Following this, the white represents 10 windows having a HVSR lower or equal, and other 10 being higher, representing the statistical mode. Panel (e) shows a sharp transition from white to black, reflecting that the change is fast; while panel (b) shows a slow degradation of color, representing a very diffuse transition at low frequencies. Hence, we conclude that the first measurement has different HVSR for every $1 \mathrm{~min}$ window, resulting in a high standard deviation, while for the second point most of the windows have the same HVSR (reflected in the low standard deviation). We processed each measurement in the same way, in order to discard those ones without a robust estimation of the predominant frequency.

After processing all the measurements, we classified each one into one of 6 groups, as shown in Figure 2, having the following classification:

a) A small amplitude peak (ranging from 3 to 5), with frequency between 1.5 and $2.5 \mathrm{~Hz}$

b) A small amplitude peak, with frequency above $2.5 \mathrm{~Hz}$

c) A small amplitude peak, with frequency below $1.0 \mathrm{~Hz}$

d) A large amplitude peak (above 5), with frequency between 0.5 and $1.0 \mathrm{~Hz}$

e) A large amplitude peak, with frequency between 1.0 and $1.5 \mathrm{~Hz}$

f) A large amplitude peak, with frequency between 1.5 and $2.5 \mathrm{~Hz}$
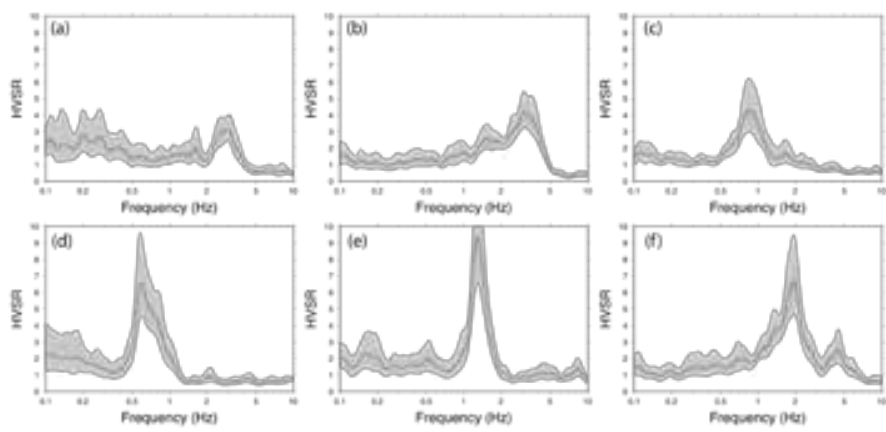

Figure 2: Classification of HVSR curves observed at Concepción

Previous studies have shown that the presence of a large HVSR amplitude peak is related to a high impedance contrast between the sedimentary cover and the basement, while a low HVSR amplitude peak is related to a lower contrast, indicating the presence of a hard soil (Woolery and Street 2002; Bonnefoy-Claudet et al. 2006a, 2008). In such cases, the peak observed in the HVSR is a good estimator of the predominant frequency of the soil (Tokimatsu 1997; Bonnefoy-Claudet et al. 2006a; 2008). 
Woolery and Street (2002) interpreted the presence of more than one peak as more than one impedance contrast at depth, while Bonnefoy-Claudet et al. (2009) relate them to higher modes. Our data presents a $25 \%$ of measurements with low amplitude (ranging from 3 to 5, cases (a) to (c) from Figure 2) and 75\% with large amplitude (greater than 5). From all of these, it is possible to estimate the predominant frequency of the soil, having $82 \%$ of the total values lower than $1.5 \mathrm{~Hz}$ (cases (d) and (e) from Figure 2).

\section{SURFACE GEOLOGY}

The main geomorphologic structures found in the area correspond to mountain belts formed by intrusive and sedimentary rocks that form the Concepción Basin, along with the fluvial sedimentary basin prairie formed by the Bio-Bío and Andalién rivers (Galli 1967). Few isolated hills are found within the basin, which are believed to be related to covered normal faults, trending NE (Ramírez and Vivallos 2009). The main geologic units found in the area are shown in Figure 3, corresponding to the following brief description:

Eocc: sandstones and continental lutites with coal lenses, Kq: calcareous sandstones with marine fossils, La: lake, PzSE: metamorphic rocks (schist, phyllite, slate), Pzg: granitic rocks (tonalities), Qbt: mud, peat, and other poorly drained materials (wetlands), Qtc: colluvial deposits, Qtfa: Andalién sands, Qtfb: BíoBío sands, Qtm: marine sand deposits, Ra: anthropic fills (artificial deposits), Tras: siliceous sands, Trg: igneous rocks (granites)

In the Greater Concepción, we found mostly Bío-Bío sands Qtfb along with artificial deposits Ra, mostly characterized by very low $(0.2$ to $1.0 \mathrm{~Hz})$ to low $(1.0$ to $1.5 \mathrm{~Hz}$ ) predominant frequencies, respectively, as shown in Figure 3. The Bío-Bío sands Qtfb are mostly finegrained materials, with increasing silts content towards the South. The sedimentary deposit thickness ranges between 50 to $130 \mathrm{~m}$ (Ramírez and Vivallos 2009); while SPT geotechnical surveys show, in average 40 blows/ft, a high level of compaction for sands at $6 \mathrm{~m}$ depth (Inostroza 2004). Mixed fluvial deposits of the Bío-Bío and Andalién rivers are made of fine grained to medium sands with abundant silts interbedded by several lenses of colluvial clays and silts. These deposits are in average $50 \mathrm{~m}$ thick and although they can have SPT values of 40 blows/ft after $7 \mathrm{~m}$ deep, they can also have very low SPT values (10 blows/ft) in the upper $15 \mathrm{~m}$. On the other hand, artificial deposits Ra can have more than $4 \mathrm{~m}$ of a heterogeneous mix of organic matter, clay, debris, and other fine-grained material with different levels of compaction.

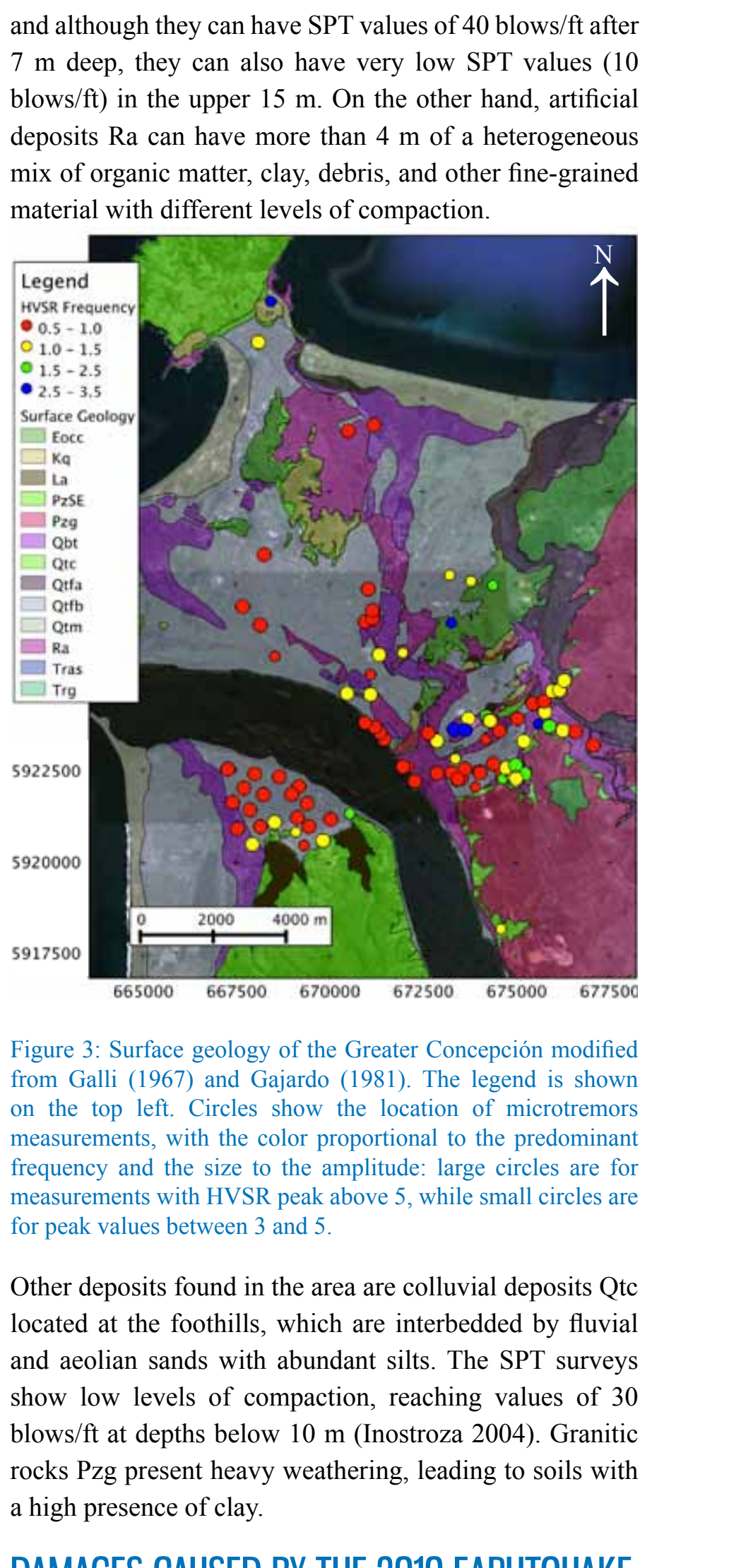

Figure 3: Surface geology of the Greater Concepción modified from Galli (1967) and Gajardo (1981). The legend is shown on the top left. Circles show the location of microtremors measurements, with the color proportional to the predominant frequency and the size to the amplitude: large circles are for measurements with HVSR peak above 5, while small circles are for peak values between 3 and 5 .

Other deposits found in the area are colluvial deposits Qtc located at the foothills, which are interbedded by fluvial and aeolian sands with abundant silts. The SPT surveys show low levels of compaction, reaching values of 30 blows/ft at depths below $10 \mathrm{~m}$ (Inostroza 2004). Granitic rocks Pzg present heavy weathering, leading to soils with a high presence of clay.

\section{DAMAGES CAUSED BY THE 2010 EARHTQUAKE}

On February $27^{\text {th }}, 2010$, Central Chile witnessed one of the largest earthquakes ever recorded $\left(\mathrm{M}_{\mathrm{w}}=8.8\right)$ that 
produced strong damage over an area of more than 400 $\mathrm{km}$ long (Astroza et al. 2010). After this large earthquake, 58 buildings in Concepción presented severe damage: 1 of them completely collapsed, 7 were on the brink of collapse, and the remaining 50 showed severe structural damage. Figure 4 shows two levels of reported damage: level 1 groups those with collapse and almost collapse and level 2 those with severe structural damage, from information given by the Municipality of Concepción. Based on these data, Ramírez and Falcón (2010) proposed the limitation of building height within Zone I of the microzonation proposed by Ramírez and Vivallos (2009), composed mainly of Bío-Bío sands Qtfb; this zone is schematically shown with dashed lines in Figure 4. This suggestion is based on the strong correlation between high intensity of observed damage and predominant periods larger than one second (Troncoso 1992) for buildings with more than 5 stories; however, further and detailed studies should be performed.

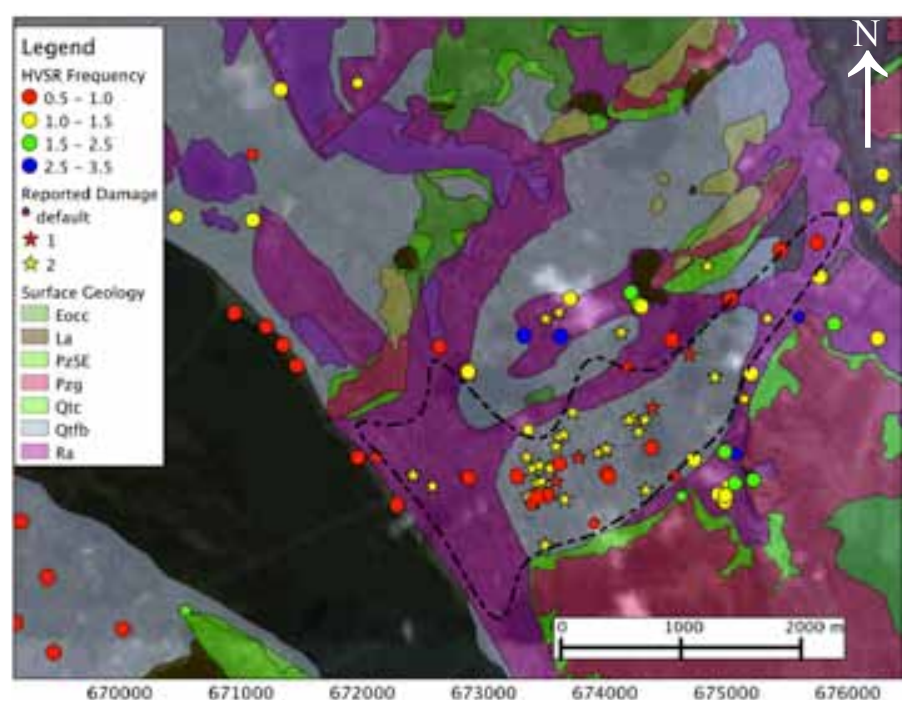

Figure 4: Surface geology of Concepción modified from Galli (1967), and the corresponding legend on the left. The stars mark the location of severely damage buildings after the Maule 2010 earthquake. Circles show the location of microtremors measurements, with the color proportional to the predominant frequency and the size to the amplitude: large circles are for measurements with HVSR peak above 5, while small circles are for peak values between 3 and 5. The dashed lines schematically marks Zone I of the microzonation proposed by Ramirez and Vivallos (2009).

The extent and intensity of damage in the Greater Concepción was very large. Figure 5 shows some examples of the inertial and liquefaction damages, widely observed in this area, especially in wetlands Qbt and anthropic fills Ra. Further information of geotechnical and structural damages can be found for example in Verdugo et al. (2010) and Betanzo (2010).
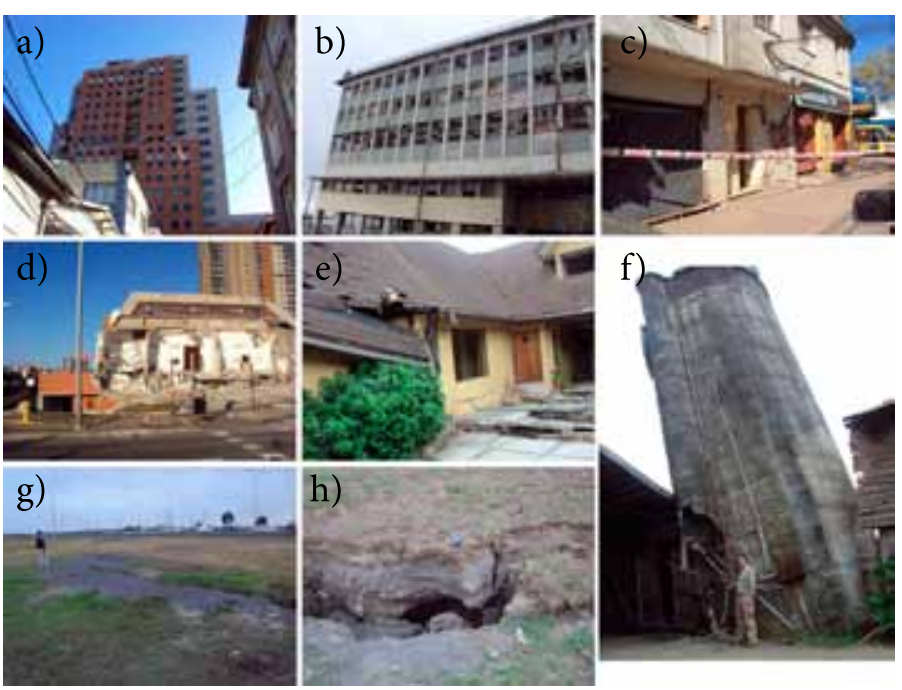

Figure 5: Damages observed in the Greater Concepción after the 2010 earthquake in buildings: a) 22 floors Torre O'Higgins in Concepción centre, b) Palacio del Deporte in Talcahuano centre, c) two floor masonry structure in Carrera Street, Concepción, d) Alto Río 15 floors building toppled over showing ceiling of ground floor, Concepción centre, e) masonry house failed due to ground's lateral spreading in Lomas de San Andrés in Concepción, and evidence of liquefaction: f) silo tilted, and g), h) sand flows and ground cracks close to the Bío Bío river in Concepción.

\section{CONCLUDING REMARKS}

Damages observed after the 2010 earthquake $\left(\mathrm{M}_{\mathrm{w}}=8.8\right)$ at Concepción were very large, especially in tall buildings. This phenomenon is probably related to the local subsurface conditions, because it was observed that nearby localities (e.g. Penco and Tomé) presented a seismic intensity of 0.5 to 1.0 points lower. We performed microtremors measurements mostly in the city of Concepción and correlated with local surface geology. Our first results confirm the extensive presence of deposits of fine-grained materials characterized by low fundamental frequencies (lower than 1.0 second).

In this study, we made a robust estimation of predominant frequency from microtremors, using a 3 component, 4.5 $\mathrm{Hz}$ geophone, in an urban enviroment. Statistical analyses of the horizontal-to-vertical spectral ratio at many 
subwindows were performed, looking for values that were predominat throughout most of the signal and discarding any transients, which made the estimation possible. After processing all the measurements, we were able to identify very low predominant frequency at Bío-Bío sands Qtfb and the anthropic fills Ra. We believe that these low predominant frequencies are one of the contributing factors for the extensive damage observed in the area.

Although the depth and shape of the basin is likely to have a significant influence in the surface strong motion of Concepción urban area, this aspect is currently being studied by the authors and is out of the scope of this work. Preliminary work on this matter shows reasonable agreement between measured fundamental periods and rock depths.

In this study we present preliminary results of a seismic microzonation of Concepción, having a large task to complete the rest of the greater urban area, including Hualpén, Talcahuano, Chiguayante and San Pedro de la Paz. Preliminarily, we found that the local geology of Concepción shows the presence of fine-grained materials characterized by low frequencies (lower than $1.0 \mathrm{~Hz}$ ). This feature should be compared with the remaining locations.

\section{Acknowledgements}

The authors would like to thank undergraduate students at Universty of Concepción, J. Alderstein, R. Bravo, P. Catalán, J. Jimenez, J. Moraga, A. Pizarro, F. Soto, and G. Spoerer for their continuous work and support in the field. The first author was funded by FONDECYT 1100551 and the second author was funded by DIUC 205.091.041-1.0. Most of the figures were made using GMT (Wessel and Smith, 1991).

\section{REFERENCES}

Astroza, M. and Monge, J. (1991). Seismic microzones in the city of Santiago. Relating damage-geological unit. Proc $4^{\text {th }}$ International Conference on Seismic Zonation, Stanford, California, August, Vol. III, 595-601

Astroza, M., Monge, J. y Varela, J. (1989). Zonificación sísmica de la Región Metropolitana. 5as. Jornadas Chilenas de Sismología e Ingeniería Antisísmica, Vol. 1, Santiago, Chile

Astroza, M., Cabezas, F., Moroni, M.O., Massone, L., Ruiz,
S., Parra, E., Cordero, F. y Mottadelli, S. (2010). Intensidades sísmicas en el área de daños del terremoto del 27 de febrero de 2010. Departamento de Ingeniería Civil, Facultad de Ciencias Físicas y Matemáticas; Universidad de Chile, Santiago, Chile.

Bard, P.Y. (1998). Microtremors measurements: a tool for site effect estimation?. Proceeding of the Second International Symposium on the Effects of Surface Geology on Seismic Motion, Yokohama, Japan, 3, 1251-1279

Bard, P.Y. and SESAME-Team (2005). Guidelines for the implementation for the $\mathrm{H} / \mathrm{V}$ spectral ratio technique on ambient vibrations-measurements, processing and interpretations. In SESAME European research project EVG1-CT-2000-00026, available at http://sesame-fp5.obs.ujf-grenoble.fr

Betanzo, R. (2010). Daños estructurales y lecciones del terremoto del 27/f en el Gran Concepción. Obras y Proyectos 8, 59-75

Bonnefoy-Claudet, S., Cornou, C., Bard, P.Y., Cotton, F., Moczo, P., Kristek, J. and Fäh, D. (2006a). H/V ratio: a tool for site effects evaluation. Results from 1-D noise simulations. Geophysical Journal International 167, 827-837

Bonnefoy-Claudet, S., Cornou, C. and Bard, P.Y. (2006b). The nature of noise wavefield and its application for sites studies: A literature review. Earth-Science Reviews 79(3-4), 205-227

Bonnefoy-Claudet, S., Köhler, A., Cornou, C., Wathelet, M. and Bard, P. Y. (2008). Effects of Love waves on microtremor H/V ratio. Bulletin of the Seismological Society of America 98(1), 288-300

Bonnefoy-Claudet, S., Baize, S., Bonilla, L.F., Berge-Thierry, C., Pasten, C., Campos, J., Volant, P. and Verdugo, R. (2009). Site effect evaluation in the basin of Santiago de Chile using ambient noise measurements. Geophysical Journal International 176(3), 925-937

Chávez-García, F.J., Dominguez, T., Rodriguez, M. and Pérez, F. (2007). Site effects in a volcanic environment: a comparison between HVSR and array techniques at Colima, Mexico. Bulletin of the Seismological Society of America 97, 591-604

Field, E.H. and Jacob K.H. (1995). A comparison and test of various site-response estimation techniques, including three that are not reference-site dependent. Bulletin of the Seismological Society of America 84(4), 1127-1143

Galli, C. (1967). Geología urbana y suelos de fundación de Concepción y Talcahuano. Informe final del proyecto de investigación $\mathrm{N}^{0} 75$, Comisión de Investigación Científica de la Universidad de Concepción, Concepción, Chile

Gajardo, A. (1981). Hoja Concepción-Chillán, región del BíoBío, 1:250.000. Mapas geológicos preliminares de Chile, 
Instituto de Investigaciones Geológicas

Inostroza, G. (2004). Metodología de estratificación y zonificación de los suelos de la Comuna de Concepción, mediante la aplicación de SIG. Memoria de Ingeniería Civil. Universidad del Bío-Bío, Concepción

Kanai, K. (1957). The requisite conditions for predominant vibration of ground. Bulletin of the Earthquake Research Institute, Tokyo University, 35, 457-470

Konno, K. and Ohmachi, T. (1998). Ground-motion characteristics estimated from spectral ratio between horizontal and vertical components of microtremor. Bulletin of the Seismological Society of America 88(1), 228-241

Lachet, C., Hatzfeld, D., Bard, P.Y., Theodulidis, N., Papaioannou, C. and Savvaidis, A. (1996). Site effects and microzonation in the city of Thessaloniki (Greece) comparison of different approaches. Bulletin of the Seismological Society of America 86(6), 1692-1703

Lermo, J. and Chávez-García F.J. (1993). Site effect evaluation using spectral ratios with only one station. Bulletin of the Seismological Society of America 83, 1574-1594

Leyton, F. and Ruiz, S. (2011). Comparison of the behavior of site from strong motion data of the 1985 Central Chile earthquake $\left(\mathrm{M}_{\mathrm{s}}=7.8\right)$ and microtremors measurements. Proceedings of the $5^{\text {th }}$ International Conference on Earthquake Geotechnical Engineering, Santiago, Chile

Leyton, F., Sepúlveda, S.A., Astroza, M., Rebolledo, S., Acevedo, P., Ruiz, S., Gonzalez, L. and Foncea, C. (2011). Seismic zonation of the Santiago Basin, Chile. Fifth International Conference on Earthquake Geotechnical Engineering, Santiago, Chile

Menéndez, P. (1991). Atenuación de las intensidades del sismo del 3 de marzo de 1985 en función de la distancia a la zona de ruptura y del tipo de suelo. Memoria de Ingeniero Civil, Universidad de Chile, Santiago.

Monge, J. (1986). El sismo del 3 de marzo de 1985, Chile. CAP, Santiago, Chile.

Montessus de Ballore, F. (1915). Historia Sísmica de los Andes Meridionales al Sur del Paralelo XVI, Quinta Parte. El Terremoto del 16 de Agosto de 1906. Soc. Imprenta-Litografía Barcelona, Santiago, Chile.

Nakamura, Y. (1989). A method for dynamic characteristics estimations of subsurface using microtremors on the ground surface. Q. Rep. Railway Tech. Res. Inst. Japan 30, 25-33

Nakamura, Y. (1996). Real-time information systems for hazard mitigation. Proceedings of the $10^{\text {th }}$ World Conference in
Earthquake Engineering, paper \# 2134.

Nakamura, Y. (2000). Clear identification of fundamental idea of Nakamura's technique and its applications. Proc. $12^{\text {th }}$ World Conference on Earthquake Engineering, Auckland, New Zealand.

Nogoshi, M., and Igarashi, T. (1970). On the propagation characteristics of microtremors (part 2). J. Seismol. Soc. Japan 23, 264-280 (in Japanese with English abstract)

Nogoshi, M. and Igarashi, T. (1971). On the amplitude characteristics of microtremors (part 2). J. Seismol. Soc. Japan 24, 26-40 (in Japanese with English abstract)

Ramírez, P. y Vivallos, J. (2009). Microzonificación sísmica de la ciudad de Concepción-Chile. XII Congreso Geológico Chileno, Santiago, Chile, S3_018

Ramírez, P. y Falcón, F. (2010). Efectos geológicos del sismo del 27 de Febrero de 2010: Calidad de los suelos, gravimetría y respuesta sísmica de los suelos, en relación al catastro de Edificios colapsados y con daños severos en la ciudad de Concepción, Región del Bio-Bío. Informe Técnico Inf-Biobio-25 del Servicio Nacional de Geología y Minería, Santiago, Chile.

Susa, D. (2004). Evaluación del peligro sísmico asociado a sismos de tipo interplaca en Chile y sur del Perú utilizando una distribución bi-paramétrica de Weibull. Memoria de Ingeniero Civil, Universidad de Chile, Santiago

Tokimatsu, K. (1997). Geotechnical site characterization using surface waves. Proceedings of the $1^{\text {st }}$ International Conference on Earthquake Geotechnical Engineering, Tokyo, Vol. 3, 1333 $-1368$

Troncoso, J. (1992). Fundamentos de Ingeniería Geotécnica Antisísmica. Ediciones Universidad Católica de Chile, Santiago, Chile

Udwadia, F.E. and Trifunac, M.D. (1973). Comparison of earthquake and microtremor ground motion in El Centro, California. Bulletin of the Seismological Society of America 63, 1227-1253

Verdugo, R., Villalobos, F., Yasuda, S., Konagai, K., Sugano, T., Okamura, M., Tobita, T. and Torres, A. (2010). Description and analysis of geotechnical aspects associated to the large 2010 Chile earthquake. Obras y Proyectos 8, 25-36

Wessel, P. and Smith, W.H.F. (1991). Free software helps map and display data. EOS Trans. $A G U, 72,441$

Woolery, E.W. and Street, R. (2002). 3D near-surface soil response from H/V ambient-noise ratios. Soil Dynamics and Earthquake Engineering 22(9-12), 865-876 